\title{
FATWA MUI NOMOR 1 TAHUN 2004 TENTANG INTEREST (STUDI TERHADAP PEMAHAMAN PEDAGANG PASAR AUR KUNING KOTA BUKITTINGGI)
}

\author{
Luthfi Rafi \\ BAZNAS Kab.Agam, luthfirafis@gmail.com \\ Basri Na'ali \\ LAINBukittinggi,basri_akif@gmail.com
}

Diterima: 5 Januari 2018

Direvisi : 27 Mei 2018

Diterbitkan: 30 Juni 2018

\begin{abstract}
Nearly one hundred percent of traders at the Yellow Aur Market are Muslim, and as Muslims they will certainly submit to Islamic rules, including using bank services in transactions. In this case in 2004 the Indonesian Ulema Council (MUI) issued a fatwa concerning the probibition of interest in the bank (interest). As a Muslim trader, the fatwa should be used as a guideline by traders in choosing the bank where they transact. But in reality most of the traders are still transacting using conventional banks that adhere to the interest system. Therefore this study will focus on understanding the Pasar Aur Kuning traders about a fatwa, and what factors cause them not to follow the MUI fatwa. This research was conducted at the Bukittinggi Yellow Aur Market, and for data collection using a questionnaire instrument. Then the analysis is done based on the method of mixing methods. The results showed that the majority of the Yellow Aur Market traders understood fatwas as legal products that may or may not be followed. In general, the factor they did not follow the fatwa was due to ignorance, incomplete Islamic bank facilities, and considered the same between interest and profit sharing.
\end{abstract}

Keywords: Fatwa, MUI, interest, Traders

\begin{abstract}
Abstrak
Hampir seratus persen pedagang di Pasar Aur Kuning beragama Islam, dan sebagai umat Islam tentunya mereka akan tunduk dengan aturan Islam, termasuk dalam menggunakan jasa bank dalam bertransaksi. Dalam hal ini pada tabun 2004 Majelis Ulama Indonesia (MUI) telah mengeluarkan fatwa tentang keharaman bunga bank (interest). Sebagai pedagang yang muslim mestinya fatwa itu dijadikean pegangan oleh pedagang dalam memilih bank tempat bertransaksi. Tetapi dalam kenyataannya sebagian besar pedagang masih bertransaksi menggunakan bank konvensional yang menganut sistem bunga. Oleh karena itu penelitian ini akan menfokuskan kepada pemahaman pedagang Pasar Aur Kuning tentang sebuah fatwa, dan apa faktor-faktor yang menyebabkan mereka tidak mengikuti fatwa MUI tersebut. Penelitian ini dilaksanakan di Pasar Aur Kuning Bukittinggi, dan untuk pengumpulan data memakai instrumen angket. Selanjutnya dilakukan analisa berdasarkan metode mixing metode. Hasil penelitian menunjukkan bahwa sebagian besar pedagang Pasar Aur Kuning memahami fatwa sebagai sesuatu produk hukum yang boleh diikuti dan boleh juga tidak diikuti. Secara umum yang menjadi faktor mereka tidak mengikuti fatwa tersebut adalah karena ketidaktahuan, tidak lengkapnya fasilitas bank syariah, dan menganggap sama antara bunga dan bagi hasil.
\end{abstract}

Kata kunci: Fatwa, MUI, interest, pedagang

\section{PENDAHULUAN}

Pada saat ini, bank merupakan sebuah tonggak besar dalam menjalankan roda perekonomian masyarakat khususnya masyarakat Indonesia. Segala sesuatu yang berkaitan dengan masalah ekonomi pasti berkaitan dengan bank. Dalam pengoperasiannya perbankan konvensional menggunakan sistem bunga. Bunga bank dapat diartikan sebagai balas jasa yang diberikan oleh bank yang berdasarkan prinsip konvensional kepada nasabah yang membeli atau menjual 
produknya. Bunga juga dapat diartikan sebagai harga yang harus dibayar kepada nasabah (yang memiliki simpanan) dengan yang harus dibayar oleh nasabah kepada bank (nasabah yang memperoleh pinjaman). ${ }^{1}$

Fiqh Islam memandang sistem bunga bank ini mengandung unsur-unsur riba karena di dalam peminjaman harta (qardh) dilarang mengambil keuntungan, karena hal ini sama dengan praktek riba jahiliyah yaitu riba nasi'ah. Syeikh Qaradhawi mengatakan bahwa praktek bunga bank itu tidak ada bedanya dengan praktek riba pada masa jahiliyah bahkan lebih jelek lagi, karena di dalam riba jahiliyah tambahan hanya terjadi apabila pada pembayaran hutang terlambat dari pada waktu yang ditentukan sedangkan pada bunga bank walaupun pembayaran tepat waktu bunga terhadap pinjaman tetap berlaku. ${ }^{2}$

Majelis Ulama Indonesia juga telah berfatwa bahwa praktek pembungaan uang saat ini telah memenuhi kriteria riba yang terjadi pada zaman Rasulullah SAW, yakni riba nasi'ah dan riba haram hukumnya. Hal ini bisa terjadi perbankan, asuransi, pasar modal, penggadaian, koperasi, dan lembaga keuangan lainnya maupun yang dilakukan oleh individu. Bagi wilayah yang sudah ada kantor/jaringan lembaga keuangan syari'ah dan mudah dijangkau, tidak dibolehkan melakukan transaksi yang didasarkan kepada perhitungan bunga. ${ }^{3}$ Tetapi setelah keluarnya fatwa ini masih sangat banyak masyarakat yang melakukan transaksi melalui bank konvensional, baik itu transaksi mengunakan giro, tabungan, ataupun meminjam dana dari bank yang menggunakan sistem bunga.

Pasar Aur Kuning merupakan salah satu pasar grosir di kawasan Sumatera yang

${ }^{1}$ Karnaen A. Perwataatmadja dan HendriTanjung, Bank Syari'ah, (Jakarta: Celestical Publishing, 2011), h. 12

${ }^{2}$ Yûsuf al-Qarâdhawî, Bunga Bank Haram, Jakarta: Akbar, 2003), h. 13

${ }^{3}$ Fatwa MUI tentang Bunga, diakses dari https://almanaar.wordpress.com/2008/04/16/fatwamui-tentang-bunga-bank/ pada tanggal 15 April 2017 tentunya tidak terlepas dari penggunaan bank. Pada umumnya pedagang di sana adalah muslim. Namun dari data yang didapatkan masih banyak pedagang yang bertransaksi menggunakan bank konvensional. Sebagai seorang muslim mestinya mereka mengikuti fatwa MUI tentang haramnya bunga bank, tetapi dalam kenyataannya tidak begitu. Mereka lebih memilih untuk bertransaksi seperti mencari pembiayaan, menabung, atau menginvestasikan uangnya pada bank konvensional dibanding ke bank syari'ah. Bahkan sebagian besar dari pedagang yang mau memulai usahanya, meminjam dana dari bank konvensional. Hal ini lah yang memotivasi untuk mengetahui bagaimana sebenarnya pedagang Pasar Aur Kuning memahami sebuah fatwa, dan apa yang menjadi faktor penyebab mereka tidak mengikuti fatwa tentang haramnya bunga ini.

\section{METODE PENELITIAN}

Jenis penelitian ini adalah studi lapangan (field research), yaitu penelitian yang dilakukan dengan menggunakan wawancara, angket atau hasil observasi penulis sendiri, Sumber data dalam penelitian ini ada dua; pertama, sumber data primer, yaitu data yang langsung dikumpulkan dari para pedagang yang berada di Pasar Aur Kuning; dan yang kedua sumber data sekunder, yaitu data yang diperoleh dari pihak lain yang terkait dengan pengurusan pasar.

Alat pengumpul data utama dalam hal ini adalah angket, yaitu sebuah alat pengumpul data yang berupa serangkaian pertanyaan yang diajukan pada responden untuk mendapatkan jawaban. Di samping itu juga dilakukan dengan wawancara terkait dengan hal-hal yang tidak ditanyakan dalam angket. Selanjutnya, setelah data diperoleh, penulis melakukan analisa data melalui pendekatan mixing metode, di mana menggabungkan antara analisa angka-angka yang didapatkan dengan deskripsi dalam bentuk kata-kata.

Untuk lebih jelasnya hasil penelitian ini 
penulis memberi pedoman penilaian dari setiap hasil dari data yang penulis kumpulkan. Pertama, untuk hasil mulai dari $0,00 \%$ sampai 19,99\% menunjukkan hasil yang sangat sedikit. Kedua, untuk hasil mulai dari $20.00 \%$ sampai $39,99 \%$ menunjukkan hasil sedikit. Ketiga, untuk hasil mulai dari 40,00\% sampai 59,99\% menunjukkan hasil cukup banyak. Keempat, untuk hasil 60,00\% sampai 79,99\% menunjukkan hasil banyak. Dan yang kelima, untuk hasil mulai dari 80,00\% sampai dengan $100 \%$ menunjukkan hasil sangat banyak.

\section{PENGERTIAN FATWA DAN FATWA DALAM MAJELIS ULAMA INDONESIA}

Kata fatwa merupakan istilah yang sudah cukup dikenal di Indonesia, dan kata ini dipahami sebagai sebuah nasehat, petuah, keputusan hukum yang diambil oleh ulama yang berwenang melakukannya untuk menjawab pertanyaan-pertanyaan yang diajukan kepadanya. Ulama-ulama yang berwenang itu di antaranya terdapat pada organisasi keislaman, seperti Majelis Ulama Indonesia (MUI). Secara kebahasaan, kata aliftâ`merupakan mashdar dari kata - أفنى - يفتى الإبانة (afta - yufti - iftâ) yang berarti 4 والإظهار (sebuah penjelasan terhadap sesuatu). Arti ini menyatakan seakan-akan kata ini menguatkan sesuatu dengan menghilangkan hal yang sulit dipahami dan menjadikannya sesuatu yang jelas. Sedangkan kata fatwa itu sendiri merupakan mashdar dari kata فتى - يفتى - (fatâ - yaffî - fatwâ atau futyâa) yang berarti al-syabb al-qawiy (pemuda yang kuat). Yûsuf al-Qarâdhâwi mengartikannya sebagai jawaban terhadap persoalan-persoalan yang sudah terjadi. ${ }^{5}$ Bentuk jamaknya adalah alfatâwŷy dengan kasrah waw, tetapi untuk meringankan bacaannya dibolehkan

\footnotetext{
${ }^{4}$ Muhammad Sulaimân Abdullah al-Asyqar, alFutyâ wa Manâhij al-iftâBabtsu Ushûliy, (Kuweit: Maktabah al-Manâr al-Islâmiyah, 1976), cet. I, h. 8

${ }^{5}$ Yûsuf al-Qarâdhâwi, al-Fatwâ Bain al-Indhibâth wa al-Tasayyub, (Kairo: Dâr al-Shahwah li al-Nasyar wa alTawzî̀, 1988), cet. I, h. 11
}

membacanya dengan al-fatâwâ dengan fathah waw. ${ }^{6}$

Sehubungan dengan dua kata fatwâ dan futyâ di atas, Ibn al-Manzhûr mengatakan bahwa kedua kata itu mempunyai makna yang sama, yaitu sama-sama dipergunakan untuk maksud al-iftâ. Untuk itu salah satu contoh yang dikemukakan oleh Ibn al-Manzhûr adalah (aku telah meminta fatwa kepadanya lalu ia memberikan fatwa kepadaku dengan sebuah penjelasan dan kekuatan). ${ }^{7}$ Akan tetapi menurut Muhammad Sulaimân al-Asyqar, kata futyâ lebih banyak dipakai dan dipergunakan dibandingkan kata fatwâ, karena kata futyâ lebih fashâhah (jelas dan lazim dalam bahasa Arab) dibandingkan kata fatwô, walaupun pemakaian kata fatwâ juga tidak mengurangi maksud yang ingin dituju. ${ }^{8}$

Menurut Imam Zamahsyari fatwa menurut arti syari'at ialah suatu penjelasan tentang hukum syari'at dalam menjawab suatu perkara yang diajukan oleh seseorang yang bertanya, baik penjelasan itu jelas/terang, atau tidak jelas (ragu-ragu) dan penjelasan itu mengarah kepada dua kepentingan yakni kepentingan pribadi atau kepentingan masyarakat banyak. ' Menurut Busyro, sebagaimana dikutip dari Sulaimân al-Asyqar, mengatakan bahwa secara definitif fatwa adalah pemberitahuan (penjelasan) tentang hukum Allah SWT yang didasarkan kepada dalil-dalil syar'i terhadap orang yang menanyakan tentang sesuatu persoalan yang sudah terjadi. Adapun pemberitahuan (penjelasan) tentang hukum Allah SWT SWT tanpa didahului oleh sebuah pertanyaan tidak disebut fatwa, tetapi diistilahkan dengan alirsyâd (memberikan penjelasan sekedar untuk

${ }^{6}$ Muhammad Jamâl al-Dîn al-Qâsimîy, al-Fatwâ fî al-Islâm, (Beirut: Dâr al-Kutub al-'Ilmiyah, 1986), cet. I, h. 48

${ }^{7}$ Muhammad ibn Mukarram ibn 'Ali Jamal al-Din Ibn al-Manzhûr, Lisan al-'Arab, (Beirut: Dar Shadir, 1414 H), Cet. Ke-3. Jilid 5, h. 145

${ }^{8}$ Muhammad Sulaimân al-Asyqar, al-Futya...., h. 7

9 Busyro, Fatwa Responsif, (Bukittinggi: STAIN Bukittinggi. 2013), h.14 
memberitahu agar seseorang menjadi cerdas), dan apabila jawaban yang didahului oleh pertanyaan tetapi tidak berkenaan dengan persoalan-persoalan yang sudah terjadi disebut dengan al-ta'lim (pengajaran). ${ }^{10}$

Namun dari sekian banyak pengertian fatwa yang dikemukakan oleh ulama, pada prinsipnya dapat dirumumuskan pengertian fatwa itu sebagai jawaban yang diberikan oleh seorang mujtahid kepada orang yang bertanya tentang ketentuan hukum syara' berkenaan dengan persoalan yang sudah terjadi, dan untuk memberikan jawaban itu seorang mujtahid terlebih dahulu melakukan proses ijtihad dengan menggali ketentuan-ketentuan hukum yang terdapat dalam al-Qur'an dan Sunnah dan dalil-dalil hukum lainnya. ${ }^{11}$

Dasar hukum fatwa yaitu:

يَا أَيَهُها الَّذِينَ آَنُوا أَطِيعُوا اللَّهَ وَاََطِيعُوا الرَّسُولَ وَأُولِي

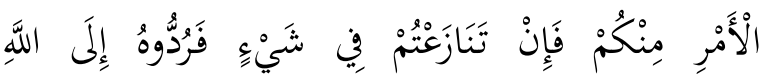

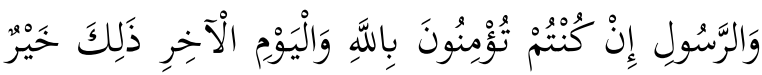

وَأَحْسَنُ تَأْوِياًا

"Hai orang-orang yang beriman, taatilah Allah dan taatilah Rasul (Nya), dan ulil amri di antara kamu. kemudian jika kamu berlainan Pendapat tentang sesuatu, Maka kembalikeanlab ia kepada Allab (Al Quran) dan Rasul (sunnabnya), jika kamu benarbenar beriman kepada Allah dan hari kemudian. yang demikian itu lebih utama (bagimu) dan lebih baik akibatnya." (Qs. An-Nisa': 59)

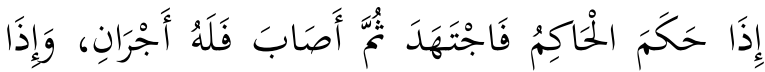

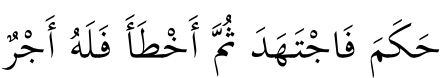

"Iika seorang hakim bendak memustuskan suatu perkara, kemudian dia berijtibad dan ijtihadnya benar, maka dia mendapat dua pabala. Tetapi jika dia berijtihad, kemudian hasil ijtihdanya salah, maka ia mendapat satu pabala." (HR al-Nasa'i)

Fatwa juga merupakan salah satu metode dalam Alquran dan Sunnah dalam

\footnotetext{
${ }^{10}$ Ibid., h. 13

${ }^{11}$ Ibid., h. 22
}

menerangkan hukum-hukum syara', ajaranajarannya, dan arahan-arahannya. Kadang penjelasan itu diberikan tanpa adanya pertanyaan atau perintah fatwa, dan cara inilah yang dominan terdapat di dalam Alquran, baik mengenal persoalan hukum maupun nasihat dan pengajaran. Namun demikian, terkadang penjelasan itu datang setelah adanya pertanyaan dan permintaan fatwa terlebih dahulu, dengan menggunakan perkataan

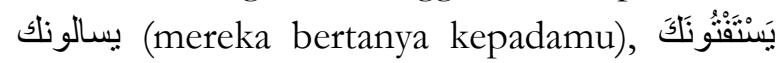
(mereka meminta fatwa kepadamu), bentuk perkataan seperti ini banyak terdapat di dalam Alquran, ${ }^{12}$ seperti:

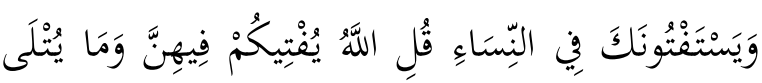

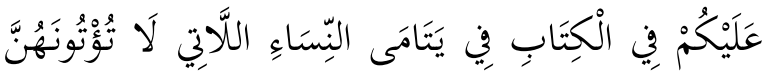

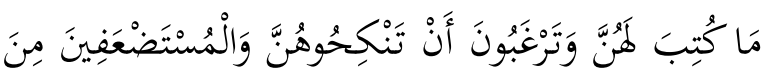

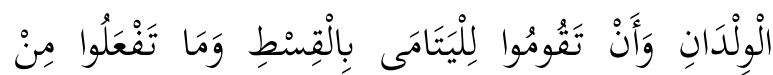

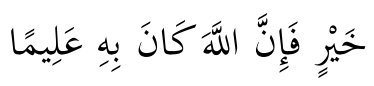
"Dan mereka minta fatwa kepadamu tentang para wanita. Katakanlab: "Allah memberi fatwa kepadamu tentang mereka, dan apa yang dibacakan kepadamu dalam Al-Quran (juga memfatwakan) tentang para wanita yatim yang kamu tidak memberikan kepada mereka apa yang ditetapkan untuk mereka, sedang kamu ingin mengawini mereka dan tentang anak-anak yang masib dipandang lemah. Dan (Allah menyurub kamu) supaya kamu mengurus anak-anak yatim secara adil. Dan kebajikan apa saja yang kamu kerjakan, maka sesunggubnya Allab adalah Maha Mengetabuinya."(QS al-Nisa :127)

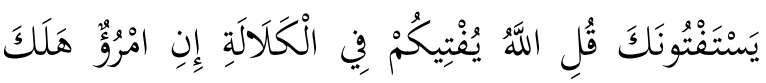

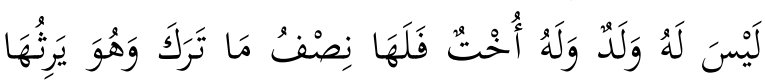

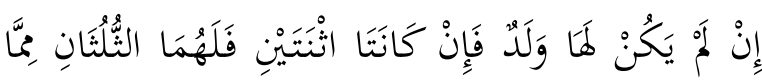

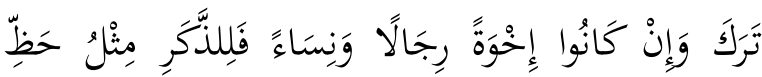

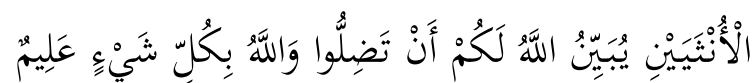
"Mereka meminta fatwa kepadamu (tentang kalalab). Katakanlah: "Allab memberi fatwa kepadamu tentang kalalah (yaitu): jika seorang meninggal dunia,

${ }^{12}$ Yusuf al-Qaradhawi, al-Fatwa..., hlm. 6 
dania tidak mempunyai anak dan mempunyai saudara perempuan, maka bagi saudaranya yang perempuan itu seperdua dari harta yang ditinggalkannya, dan saudaranya yang laki-laki mempusakai (selurub harta saudara perempuan), jika ia tidak mempunyai anak; tetapi jika saudara perempuan itu dua orang, maka bagi keduanya dua pertiga dari harta yang ditinggalkan oleh yang meninggal. Dan jika mereka (abli waris itu terdiri dari) saudara-saudara laki dan perempuan, maka bahagian seorang saudara laki-laki sebanyak bahagian dua orang saudara perempuan. Allab menerangkan (bukum ini) kepadamu, supaya kamu tidak sesat. Dan Allah MabaMengetahui segala sesuatu."(QS.An-Nisa':176)

Kedua ayat di atas menggunakan kata al-ifta' untuk meminta penjelasan kepada Rasulullah SAW tentang persoalan wanita dan kalalah. Dari contoh di atas dapat dipahami bahwa untuk meminta penjelasan kepada seseorang ulama tentang hukum syar'i, dapat dilakukan dengan menggunakan kata al-ifta dan kata-kata lain yang semakna dengannya. Dalam ayat tersebut dapat dipahami bahwa sebuah fatwa terlebih dahulu diawali dengan pertanyaan-pertanyaan tetang persoalanpersoalan tertentu kemudian diakhiri dengan al-ifta` atau al- fatwa yaitu berupa penjelasan Allah SWT terhadap persoalan yang dipertanyakan.

Sementara itu, di dalam Sunnah ada kalanya Rasulullah SAW menerangkan hukum suatu masalah secara langsung tanpa diketahui pertanyaan dari seseorang. Biasanya hal seperti ini beliau lakukan untuk menghilangkan kesalahpahaman, untuk membetulkan pengertian, mengajarkan kepada orang yang tidak tahu, memantapkan hati orang yang sedang menuntut ilmu, untuk mengkhususkan yang umum atau memberi qayid (ketetapan) bagi yang mutlak (tidak terikat), sebagai penjelasan Nabi SAW terhadap Alquran, atau untuk tujuan lainnya.

Adakalanya juga sebagai jawaban bagi suatu pertanyaan, dan yang demikian ini banyak sekali jumlahnya. Misalnya, pertanyaan Abu Musa al-Asy'ari : "Wahai Rasulullah, berilah fatwa kepada kami tentang minuman yang kami buat di Yaman yang disebut al-bi'qu yang berasal dari madu yang dijadikan minuman keras, dan al-mizru yang terbuat dari jagung dan gandum hingga menjadi minuman keras. Maka Rasulullah SAW menjawab :

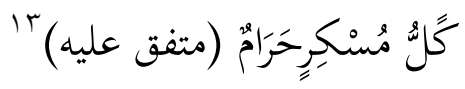

"Semua yang memabukkan (mengbilangkan kesadaran akal) adalah haram." (HR. Muttafaqun 'Alaib).

Tharid bin Said pernah bertanya kepada beliau tentang khamar, lalu beliau melarangnya membuat khamar. Namun, Thariq berkata : "Aku hanya membuatnya untuk obat. Maka beliau bersabda :

$$
\text { إنَّهَ لَيْسَ بِدَوَاءٍ, وَلَكِنَّهُ دَاءُ (رواه مسلم) } 1
$$

"Sesunggubnya khamar (minuman keras) itu bukan obat, melainkan penyakit." (HR. Muslim)

Aisyah r.a pernah bertanya kepada Rasulullah SAW seraya berkata : "Sesungguhnya suatu kaum datang kepada kami dengan membawa daging, sedangkan saya tidak tahu apakah daging itu disebutkan nama Allah pada waktu menyembelihnya atau tidak". Maka beliau bersabda :

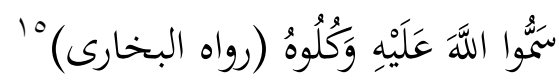

"Sebutlah nama Allab olehmu dan makanlah. "(HR. Bukhari)

Beliau pun pernah ditanya tentang seseorang yang berperang hanya untuk menunjukkan keberaniannya, orang yang berperang karena fanatik kepada kaumnya, dan orang yang berperang karena ingin disanjung orang lain, manakah di antara mereka yang

13 Muhammad ibn Ismâ'îl Abû 'Abdillah alBukhârî, al-Jâmi' al-Musnad al-Shahîh al-Mukhtashar min Umûr Rasûlillah SAW wa Sunanub wa Ayyâmuh, (Damaskus: Dâr Thûq al-Najâh, 1422 H), cet. Ke-1, juz 5, h. 161

${ }^{14}$ Muslim ibn al-Hajjâj Abû al-Hasan al-Qusyairi al-Naisabûrî, Musnad al-Șahîh al-Muktașar bi Naql al-adl Ilâ Rasûlillâh $S A W$, (Beirut: Dâr Ihyâ' al-Turâs al-'Arabi, [tth]), Juz 3, h. 1573

${ }^{15}$ Al-Bukhârî, al-Jâmi' al-Musnad..., juz 3, h. 53 
digolongkan fii sabilillah ? Lalu beliau menjawab :

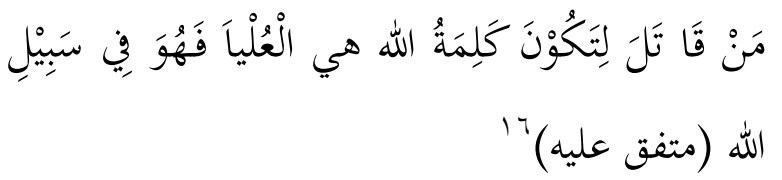

"Barang siapa yang berperang karena ingin menjunjung tinggi kalimat (agama) Allah, maka dia itulab yang tergolong fii sabilillah" (HR. Muttafaqun 'Alaib).

Fatwa-fatwa Rasulullah SAW terhadap para penanya dalam sebagian besar persoalan syari'at dan berbagai persoalan hidup sangatlah luas, banyak, dan beraneka ragam, yang tidak akan menimbulkan keraguan bagi orang yang mau mengkaji sunnah beliau.

Untuk mengeluarkan sebuah fatwa, seorang mufti, selaku seorang ahli fiqh (faqih) yang akan melahirkan hukum-hukum Islam berdasarkan ijtihad, sebelum mengeluarkan sebuah fatwa harus terlebih dahulu memenuhi beberapa syarat. ${ }^{17}$ Ulama ushul fiqih berbeda pendapat tentang syarat untuk menjadi seorang mufti, namun secara umum dapat disimpulkan bahwa seorang mufti itu haruslah orang yang menguasai bidang fiqh, baik itu ushul figh dan figh itu sendiri beserta pendapat yang ada di dalamnya $;{ }^{18}$ menguasai ilmu Bahasa Arab; ${ }^{19}$ menguasai ilmu tafsir; menguasai ilmu hadis; mengetahui tempattempat ijma', karena ijma, merupakan sumber hukum ketiga setelah Alquran dan Sunnah, dan derajat ijma' sama dengan hadist muttawatir; dan mengetahui maqashid syari'ah (tujuan syariat) secara umum, karena bagaimanapun juga syariat itu berkaitan dengan maqashid syariah atau maksud (rahasia) disyariatkannya suatu hukum. ${ }^{20}$ Dan

16 Al-Bukhârî , al-Jâmi' al-Musnad ..., juz 1, h. 36; Muslim, Musnad al-Sahîh..., juz 3, h. 1512

${ }^{17}$ Busyro, Fatwa..., h. 23

${ }^{18}$ Asymuni A. Rahman, dkk, Ushul Figh QaidahQaidah Istinbath dan Ijtihad, (Jakarta: Departemen Agama, 1986), h. 118

${ }^{19}$ Abdul Wahab Khallaf, Ilmu Ushul Figh, (Semarang: Dina Utama, 1994), h. 340

${ }^{20}$ Busyro, Fatwa..., h. 25 juga seorang mufti harus memiliki kepribadian yang baik; santun; berwibawa; berkecukupan dalam materi; dan memiliki ilmu tentang kemasyarakatan. $^{21}$ Setelah seorang mufti memenuhi persyaratan tersebut barulah mufti tersebut boleh mengeluarkan fatwa. Dan bagi orang yang meminta fatwa atau mustafti hendaklah ia menanyakan hal-hal yang bermanfaat, selalu bertaqwa kepada Allah SWT, memahami setiap fatwa yang diterima, dan selalu melandasi niatnya untuk menuntut ilmu karena Allah SWT. ${ }^{22}$

Di Indonesia, ada sebuah lembaga sering mengeluarkan fatwa masalah keagamaan, lembaga itu adalah Majelis Ulama Indonesia. Sebuah lembaga yang menjadi tempat bermusyawarahnya para ulama, zuama dan cendekiawan muslim Indonesia. Dan lembaga ini bertujuan untuk memberikan bimbingan dan tuntunan kepada umat Islam Indonesia dalam mewujudkan kehidupan beragama dan bermasyarakat yang diridhoi Allah Subhanahu wa Ta'ala; memberikan nasihat dan fatwa mengenai masalah keagamaan dan kemasyarakatan, meningkatkan kegiatan bagi terwujudnya ukhwah Islamiyah dan kerukunan antar-umat beragama dalam memantapkan persatuan dan kesatuan bangsa serta; menjadi penghubung antara ulama dan umaro (pemerintah) dan penterjemah timbal balik antara umat dan pemerintah guna mensukseskan pembangunan nasional. ${ }^{23}$

Dalam hal berfatwa Majelis Ulama Indonesia selalu berpedoman kepada dasardasar umum penetapan fatwa yang tertuang dalam SK Dewan Pimpinan Majelis Ulama Indonesia U-596/MUI/X/1997 bab 2 pasal 2 yang terdiri dari tiga ayat, yaitu; setiap fatwa yang dikeluarkan harus didasarkan atas Kitabullah dan Sunnah Rasul yang mu'tabarah,

${ }^{21}$ Asymuni A. Rahman, dkk, Ushul Fiqh..., h. 179

${ }^{22}$ Yûsuf al-Qarâdhawî, Fatwa Antara Ketelitian dan Kecerobohan, (Jakarta: GemaInsani, 1997), h.

${ }^{23}$ Anwar Abbas, dkk, Pedoman Penyelenggaraan Organisasi Majelis Ulama Indonesia, (Jakarta: Majelis Ulama Indonesia, 2010), h. 7 
serta tidak bertentangan dengan kemaslahatan umat; jika tidak terdapat di dalam Kitabullah dan Sunah Rasul, fatwa hendaklah tidak bertentangan dengan ijma, qiyas yang mu'tabar, dan dalil-dalil hukum lain, seperti istihsan, masalih mursalah dan sadduzzari'ah; dan sebelum mengambil fatwa hendaklah diambil pendapat-pendapat para imam mazhab terdahulu, baik yang berhubungan dali-dalil hukum maupun yang berhubungan dengan dalil yang dipergunakan oleh pihak yang berbeda pendapat, serta pandangan penasihat ahli yang dihadirkan. ${ }^{24}$

Ketentuan ini merupakan kesepakatan dan keyakinan umat Islam bahwa setiap fatwa harus didasarkan kepada kedua sumber hukum yang disepakati tersebut. Fatwa yang bertentangan atau yang tidak didasarkan dengan Alquran dan Sunnah dipandang tidak sah. Bahkan dipandang sebagai tahakkum dan perbuatan dusta atas nama Allah yang sangat di larang agama. ${ }^{25}$ Jadi, pedoman yang digunakan Majelis Ulama Indonesia dalam berfatwa sesuai dengan syarat mufti yang dikatakan oleh ulama fiqh klasik.

\section{INTEREST DAN RIBA}

Secara bahasa interest berarti bagian, kepentingan, dan bunga. ${ }^{26}$ Sedangkan secara istilah menurut The American Heritage Dictionary of the English Language interest adalah sejumlah uang yang dibayar untuk penggunaan modal, dan jumlah uang tersebut biasanya satu persen dari jumlah modal. ${ }^{27}$ Bunga bank dapat diartikan sebagai balas jasa yang diberikan oleh bank yang berdasarkan prinsip konvensional kepada nasabah yang membeli atau menjual produknya. Bunga bagi bank juga dapat diartikan sebagai harga yang harus dibayarkan

\footnotetext{
${ }^{24}$ Ma'ruf Amin, M. Ichwan Sam, dkk, Himpunan Fatwa Majelis Ulama Indonesia Sejak 1975, Jakarta: Erlangga, 2011), h. 14

${ }^{25}$ Ibid., h.15

26Desi Anwar, Kamus Lengkap Satu Milliard, (Surabaya: Amelia, 2003), h. 191

${ }^{27}$ Wirdyaningsih, Bank dan Asuransi Islam di Indonesia, (Jakarta: Kencana Prenada Media, 2005), h.18
}

kepada nasabah yang memiliki simpanan (bunga simpanan) dan harga yang harus dibayar oleh nasabah kepada bank nasabah yang memperoleh pinjaman (bunga pinjaman).

Kedua macam bunga ini merupakan komponen utama faktor biaya dan pendapatan bagi bank. Bunga simpanan merupakan biaya dana yang harus dikeluarkan kepada nasabah sedangkan bunga pinjaman merupakan pendapatan yang diterima dari nasabah. Baik bunga simpanan maupun bunga pinjaman masing-masing saling mempengaruhi satu sama yang lainnya. Sebagai contoh seandainya bunga simpanan tinggi, maka secara otomatis bunga pinjaman juga ikut naik dan demikian pula sebaliknya. $^{28}$

Secara garis besar faktor-faktor yang mempengaruhi besar kecilnya bunga adalah faktor kebutuhan bank akan dana, ada dana itu yang bersumber dari dalam bank, ada juga dana itu yang bersumber dari masyarakat (seperti simpanan giro, simpanan tabungan, dan simpanan deposito); ${ }^{29}$ faktor persaingan antar bank untuk memperebutkan dana dari nasabah; Faktor kebijakan pemerintah yang membatasi jumlah maksimal dan minimal bank boleh menetapkan suku bunga; ${ }^{30}$ faktor adanya target laba yang diinginkan oleh bank, jika bank ingin laba yang besar maka bank menetapkan suku bunga yang tinggi untuk bunga pinjaman; ${ }^{31}$ faktor jangka waktu, semakin lama nasabah meminjam dana ke bank, semakin besar bunga yang dibebankan bank kepada nasabah; dan faktor kualitas pinjaman, semakin bagus barang jaminan atau terjaminnya dana akan dikembalikan nasabah semakin rendah suku bunga yang dibebankan oleh bank kepada nasabah.

Dan macam-macam pembebanan suku bunga itu ada yang dibebankan setiap bulannya

\footnotetext{
${ }^{28}$ Kasmir, Dasar-dasar Perbankan, (Jakarta: Raja Grafindo Persada, 2002), h.134

${ }^{29}$ I WayanSudirman, Manajemen Perbankan, (Jakarta: Kencana Prenada, 2013), h. 172

${ }^{30}$ Herman Darmawi, Pasar Finansial dan LembagaLembaga Finansial, (Jakarta: Bumi Aksara, 2006) h. 187

${ }^{31}$ Kasmir, Dasar-dasar Perbankan..., h.135
} 
dengan jumlah bunga yang tetap (flat rate), ada pembebanan bunga itu setiap bulannya di hitung dari sisa pinjaman atau sisa hutang (sliding rate), dan ada pembebanan bunga itu, dan ada pembebanan bunga itu berdasarkan besarnya suku bunga yang ada di pasaran (floating rate). ${ }^{32}$

Kemudian riba, secara bahasa riba berarti bertambah (ziyadah), dan kelebihan. Secara istilah riba menurut Mazhab Hambali riba adalah tambahan pada barang-barang tertentu. Menurut Mazhab Hanafi di dalam kitab Khanzul Ummal riba' diartikan sebagai tambahan tanpa imbalan dalam transaksi harta dengan harta. Maksud tambahan disini adalah tambahan harta meskipun secara hukmi saja, sehingga definisi ini mencakup riba nasiah, dan jenis-jenis akad jual beli yang fasid (rusak). Hal itu dilihat dari sisi bahwa penundaan penyerahan salah satu barang yang ditukarkan merupakan tambahan secara hukmi tanpa adanya imbalan materi yang nyata. Penangguhan ini pada umumnya diberikan dengan imbalan tambahan. ${ }^{33}$ Menurut Imam Ahmad bin Hanbal yang dikatakan riba adalah seseorang memiliki hutang, maka dikatakan kepadanya apakah akan melunasi atau membayar lebih. Jika tidak mampu melunasi, ia harus menambah dana atas penambahan masa yang diberikan. ${ }^{34}$

Dari beberapa defenisi di atas, secara umum riba adalah suatu penambahan yang diminta oleh debitur kepada kreditur, karena kreditur tidak mampu membayar hutangnya pada waktu yang telah ditentukan. ${ }^{35}$ Hukum memakan riba haram, larangan riba yang terdapat di dalam Alquran tidak diturunkan oleh Allah SWT sekaligus, melainkan diturunkan dalam empat tahap. Tahap pertama

\footnotetext{
${ }^{32}$ Ibid., h.140

${ }^{33}$ Wahbah al-Zuhaily, Figh Islam wa Adillatuhu (terjemahan), (Jakarta: Gema Insani, 2011), h. 307

${ }^{34}$ Syukri Iska, Sistem Perbankan Syariah di Indonesia dalam Perspektif Fiqih Ekonomi, (Yogyakarta: Fajar Media Press, 2012), h. 217

${ }^{35}$ Siah Khosyi'ah, Fiqh Muamalah Perbadingan, (Bandung: Pustaka Setia, 2014), h. 169
}

Peringatan Allah SW'T mengenai riba di dalam Alquran adalah menolak anggapan bahwa pinjaman riba secara zahirnya seolah-olah menolong mereka yang memerlukan sebagai suatu perbuatan mendekati atau taqarrub kepada Allah SWT dalam Alquran Surah alRum ayat $39:^{36}$

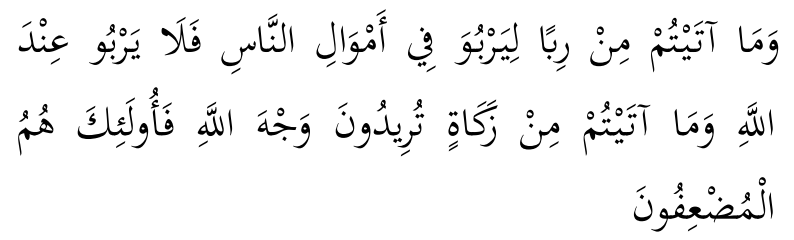

"Dan sesuatu riba (tambahan) yang kamu berikan agar dia bertambah pada harta manusia, maka riba itu tidak menambah pada sisi Allah. Dan apa yang kamu berikan berupa zakat yang kamu maksudkan untuk mencapai keridhaan Allah, maka (yang berbuat demikian) itulah orang-orang yang melipat gandakan (pahalanya)."(QS. Ar-Rum: 39)

Pada tahap kedua, riba digambarkan sebagai suatu yang buruk. Allah SWT mengancam akan memberi balasan yang keras kepada orang Yahudi yang memakan riba. ${ }^{37}$ Allah SW'T berfirman di dalam Surat al-Nisa` ayat 160-161:

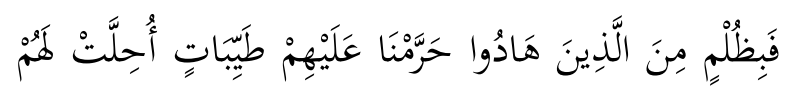

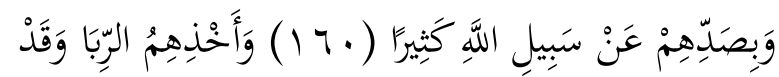

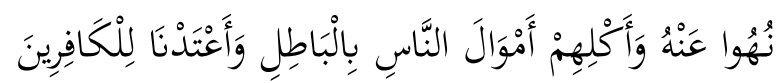

$$
\text { مِنْهُمْ عَذَابًا أَلِيمًا (1) }
$$

"Maka disebabkan kezaliman orang-orang Yabudi, Kami haramkan atas (memakan makanan) yang baik-baik (yang dabulunya) dibalalkan bagi mereka, dan karena mereka banyak menghalangi (manusia) dari jalan Allah, dan disebabkan mereka memakan riba, Padabal Sesunggubnya mereka telah dilarang daripadanya, dan karena mereka memakan barta benda orang dengan jalan yang batil. Kami telah menyediakan untuk orang-orang yang kafir di antara mereka itu siksa yang pedih."'(QS. An-Nisa': 160161).

36Zainuddin Ali, Hukum Perbankan Syariah, (Jakarta: Sinar Grafika, 2010), h. 100

${ }^{37}$ Muhammad Syafi'i Antonio, Bank Syari'ah dari Teori ke Praktik, (Jakarta: Gema Insani, 2013), h. 49 
Pada tahap ketiga, peringatan Allah SWT dalam al-Qur'an mengenai riba yang berlipat ganda. Riba yang diharamkan dengan dikaitkan kepada suatu tambahan yang berlipat ganda. Para ahli tafsir berpendapat, bahwa pengambilan bunga dengan tingkat yang cukup tinggi merupakan fenomena yang banyak dipraktikkan pada masa tersebut. ${ }^{38}$ Allah SWT berfirman dalam surat Ali Imran ayat 130:

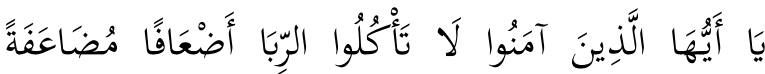

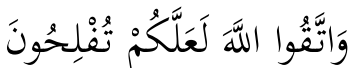

"Hai orang-orang yang beriman, janganlah kamu memakan riba dengan berlipat ganda dan bertakwalah kamu kepada Allah Supaya kamu mendapat keberuntungan."(QS. Ali-Imran: 130)

Ayat ini turun pada tahun ke tiga Hijriah. Secara umum, ayat ini harus dipahami bahwa kriteria berliapat ganda bukanlah merupakan syarat terjadinya riba, tetapi ini merupakan sifat umum dari praktik pembungaan pada saat itu.

Dan tahap keempat, Peringatan Allah SWT dalam al-Qur'an sebagai peringatan terakhir mengenai riba secara jelas dan tegas mengharamkan riba dalam berbagai jenis tambahan yang diambil dari pinjaman. ${ }^{39}$ Allah Berfirman dalam surat Al-Baqarah ayat 278279:

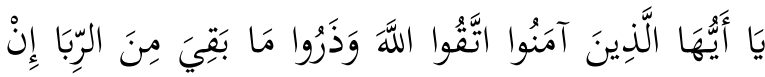

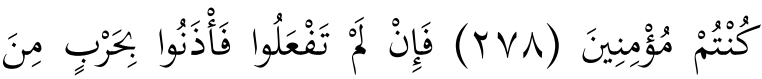

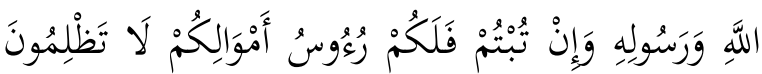

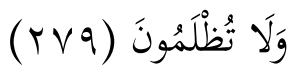

"Wabai orang-orang yang beriman, bertaqwalah kepada Allah dan tinggalkanlah sisa-sisa riba (yang belum dipungut) jikea kamu orang-orang yang beriman. Maka jika kamu tidak mengerjakan (meninggalkan sisa riba), Maka Ketabuilah, babwa Allah dan rasul-Nya akan memerangimu. dan jika kamu bertaubat (dari pengambilan riba), Maka bagimu pokok hartamu; kamu tidak menganiaya dan tidak (pula) dianiaya."'(QS. Al-Baqarah : 278-279)

\footnotetext{
${ }^{38}$ Zainuddin Ali, Hukum..., h. 101

${ }^{39}$ Muhammad Syafi'i Antonio, Bank..., h. 50
}

Dan Allah SWT berfirman dalam surat al-Baqarah ayat 275:

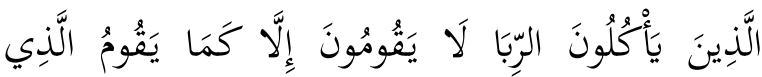

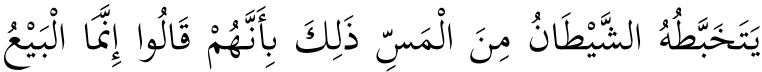

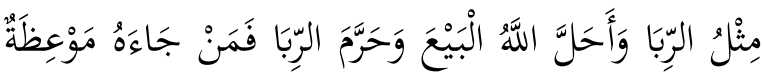

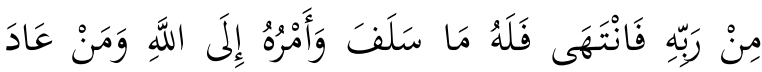

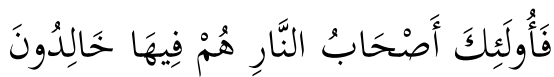

"Orang-orang yang memakan (mengambil) riba tidak dapat berdiri melainkan seperti berdirinya orang yang kemasukan syaitan lantaran (tekanan) penyakit gila. Keadaan mereka yang demikian itu, adalah disebabkan mereka berkata (berpendapat), Sesunggubnya jual beli itu sama dengan riba, Padahal Allah telah menghalalkan jual beli dan mengharamkan riba Barang siapa yang telah sampai kepadanya larangan dari Tuhannya, lalu terus berhenti (dari mengambil riba), maka baginya apa yang telah diambilnya dahulu (sebelum datang larangan); dan urusannya (terserah) kepada Allah. Orang yang kembali (mengambil riba), maka orang itu adalah penghuni-penghuni neraka; mereka kekal di dalamnya."(QS. Al-Baqarah :275)

Selain nash-nash Alquran, dalil pengharaman riba ini juga terdapat di dalam hadis Rasulullah SAW, antara lain:

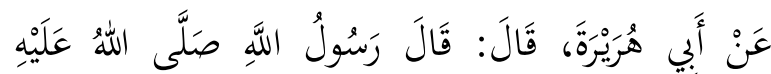

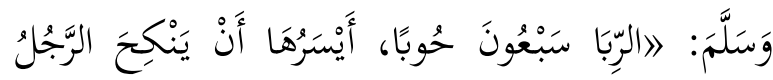

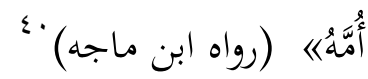

"Dari Abu Hurairah RA bahwa Nabi SAW bersabda: "Riba itu mempunyai 70 pintu, yang paling ringan ialah seperti seorang laki-laki menikahi ibunya”. (HR. Ibn Majab)

$$
\begin{aligned}
& \text { عَنْ جَابِرٍ رضي الله عنه قَالَ: ( لَعَنَ رَسُولُ الَلَّهِ صلى }
\end{aligned}
$$

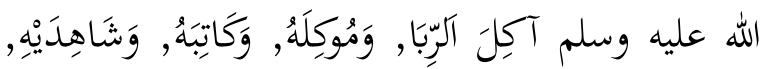

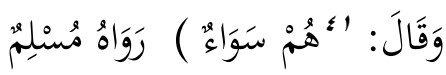

40 Ibn Mâjah Abû Abdillâh Muhammad ibn Yazîd al-Quzwainîy, Sunan Ibn Mâjah, (Dâr al-Ihyâ`al-Kutub al-'Arabiyah, [tth]), juz 2, h. 764

${ }^{41}$ Muslim, Musnad al-Shahih..., juz 3, h. 1219 
'Tabir Radliyallaabu 'anbu berkata: Rasulullah Shallallaahu 'alaihi wa Sallam melaknat pemakan riba, pemberi makan riba, penulisnya, dan dua orang saksinya. Beliau bersabda: "Mereka itu sama." (HR. Muslim)

Pembagian riba menurut jumhur ulama ada dua macam, yaitu riba fadhl dan riba nasi ah, dan menurut imam Syafi'i ada satu macam lagi yaitu riba yad. Menurut ulama Hanafiah riba fadhl adalah riba yang merupakan jual beli sebagai tambahan pada harta dalam akad jual beli sesuai dengan ukuran syari'at (yaitu takaran atau timbangan), jika barang yang ditukar sama. ${ }^{42}$ Menurut Sayyid Sabiq riba fadhl adalah jual beli uang dengan uang atau barang dengan barang dengan tambahan. ${ }^{43}$ Riba fadhl juga diartikan dalam hal terjadinya pertukaran barang dengan barang (jual beli barter) yang tidak sama kuantitasnya dan dengan pembayaran yang ditangguhkan, seperti gandum, padi, lembu, uang, kambing dan lain sebagainya. Berdasarkan hadist Rasulullah SAW :

وَعَنْ أَبْي هُرَيْرَةَ رضي الله عنه قَالَ: قَالَ رَسُولُ آلَّهِ صلى

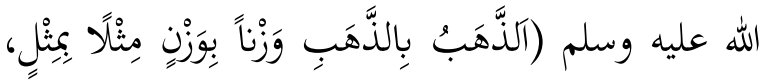

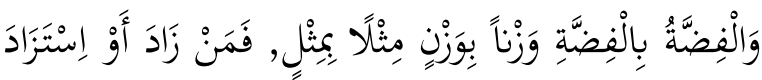

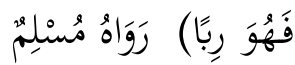

"Dari Abu Hurairah RA babwa Rasulullab $S A W$ bersabda: "(Diperbolebkean menjual) emas dengan emas yang sama timbangannya dan sama sebanding, dan perak dengan perak yang sama timbangannya dan sama sebanding. Barangsiapa menambab atau meminta tambahan maka itu riba."(HR. Muslim)

Kemudian riba nasiah, yaitu penambahan bersyarat yang diperuntukan bagi yang memberi hutang, yang diperoleh dari orang yang berhutang karena adanya penagguhan pembayaran. Dengan demikian, riba ini muncul ketika seseorang melakukan

${ }^{42}$ Wahbah al-Zuhaily, Fiqih..., h. 309

${ }^{43}$ Sayyid Sabiq, Fikib Sunnah 5, (Jakarta: Cakrawala Publishing, 2012), h. 227

${ }^{44}$ Muslim, Musnad al-Shabih..., juz 3, h. 1212 penundaan pembayaran terhadap hutangnya, ketika itu pihak pemberi hutang menyetujui penundaan pembayaran hutang menyetujui penundaan pembayaran hutang dengan syarat ada penambahannya. Riba dalam jenis transaksi ini sangatlah jelas dan tidak perlu diterangkan sebab semua unsur dasar riba telah terpenuhi semua seperti tambahan dari modal, dan tempo yang menyebabkan tambahan. Dan menjadikan keuntungan (interest) sebagai syarat yang terkandung dalam akad yaitu harta melahirkan harta karena adanya tempo. ${ }^{45}$

Riba jenis ini diharamkan berdasarkan Alquran, Sunnah, dan ijma' para imam. Allah berfirman dalam surat al-Baqarah ayat 278-279

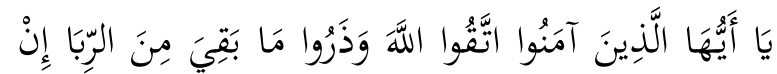

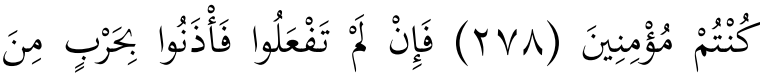

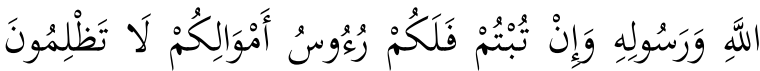
وَلَا تُظْلَمُونَ (rvq)

"Hai orang-orang yang beriman, bertakwalah kepada Allah dan tinggalkean sisa riba (yang belum dipungut) jika kamu orang-orang yang beriman. Maka jika kamu tidak mengerjakan (meninggalkan sisa riba), Maka Ketahuilah, babwa Allab dan rasul-Nya akan memerangimu. dan jika kamu bertaubat (dari pengambilan riba), Maka bagimu pokok bartamu; kamu tidak menganiaya dan tidak (pula) dianiaya." (QS. Al-Baqarah :278-279)

Dan terakhir pembagian riba menurut ulama Syafi'iah, yaitu riba yad. Riba yad yaitu jual beli dengan menunda penyerahan kedua barang atau menyerahkan salah satu barang tapi tanpa menyebutkan waktu penangguhan. Maksudnya, akad jual beli barang yang tidak sejenis, seperti gandum dengan jelai, tanpa menyerahkan barang dimajelis akad. Jenis riba ini termasuk dalam defenisi riba nasiah menurut ulama Hanafiyah, yaitu penambahan barang pada utang. Defenisi ini muncul dari syarat penyerahan kedua barang ribawi di majelis akad. Dalam riba ini terjadi

\footnotetext{
${ }^{45}$ Abdul Aziz Muhammad Azzam, Fiqih..., h. 222
} 
penangguhan penyerahan kedua barang atau salah satunya dengan tindakan kedua pihak bukan dengan persyaratan penangguhan. ${ }^{46}$

Untuk menetapkan apa yang dikatakan riba, ulama berbeda pendapat mengenai illatnya. Para ulama Hanafiah berpendapat bahwa illat riba fadhl adalah barang yang ditakar atau ditimbang dengan kesamaan dalam jenisnya dan illat riba nasiah adalah adanya salah satu dari dua sifat riba fadhl, yaitu takaran, timbangan atau kesamaan jenis barang. ${ }^{47}$ Menurut ulama Malikiah, yang menjadi illat pengharaman riba fadhl ada dua hal, yaitu bahan pokok dan dapat disimpan, dan illat riba nasi'ah adalahbarang yang dapat dimakan selain untuk pengobatan, baik termasuk bahan pokok dan dapat disimpan, atau hanya merupakan bahan pokok saja, maupun bukan merupakan bahan pokok yang dapat disimpan, seperti berbagai jenis sayursayuran seperti labu, semangka, jeruk lemon, sawi, wortel, dan talas. Juga merupakan buahbuahan seperti ruthab (kurma basah), apel dan pisang.

Menurut ulama Syafi'iah illat riba adalah makanan dan nilai (bagi emas dan perak).Menurut ulama Hambali terdapat tiga riwayat mengenai illat riba. Yang paling masyhur di antara tiga riwayat ini adalah seperti mazhab Hanafi, yaitu bahwa illat riba adalah takaran atau timbangan dengan kesamaan jenis barang. Sehingga riba terjadi pada setiap barang sejenis yang ditakar dan ditimbang, baik barang itu berupa makanan maupun bukan, seperti biji-bijian, kapur, kapas, kain, besi dan lainnya. Riba tidak terjadi pada pertukaran makanan yang sejenis yang tidak ditakar atau ditimbang.

Riwayat kedua adalah sama dengan illat yang dikemukakan oleh ulama Syafi'iyah. Dan riwayat ketiga, selain pada emas dan perak adalah pada setiap makanan yang ditimbang, sedangkan pada makanan yang tidak ditimbang

${ }^{46}$ Wahbah al-Zuhaily, Fiqih..., h. 311

${ }^{47}$ Nasrun Haroen, Fiqh Muamalah, (Jakarta: Gaya Media Pratama, 2000), h. 265 tidak dikategorikan riba, walaupun ada tambahan. ${ }^{48}$ Hal ini sesuai dengan pendapat Said Ibn Musayyab yang yang mendasarkan pendapatnya pada hadis Rasulullah SAW:

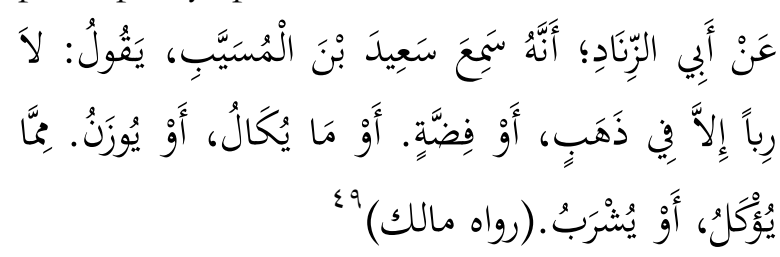

"Dari Abu Zannad sesunggubnya ia mendengar Sa'id ibn Musayyab berkata, "Tidak ada riba kecuali pada emas atau perak atau sesuatu yang bisa ditakear dan ditimbang dari apapun yang dimakan dan diminum”. (HR. Malik).

Dan yang terakhir menurut ulama Zahiriyah, menurut golongan ini, riba tidak dapat di-illat-kan, sebab ditetapkan dengan nash saja. Dengan demikian, riba hanya terjadi pada barang-barang yang telah ditetapkan pada hadis di atas, yaitu enam macam sebab golongan ini mengingkari adanya qiyas. Jadi dapat ditarik kesimpulan bahwa, untuk menghindari riba dalam transaksi barangbarang ribawi (emas, perak, gandum, dan lainnya) haruslah barang yang ditukarkan tersebut sama nilainya, sama ukurannya, dan diserahkan di dalam majelis akad. ${ }^{50}$

Kemudian, mengenai bunga uang yang terjadi pada saat sekarang ini, organisasiorganisasi Islam Indonesia telah mengkaji dan mengeluarkan fatwa, di antaranya, Majelis Tarjih Muhammadiyah yang mengatakan bunga yang diberikan oleh bank-bank milik negara kepada para nasabahnya atau sebaliknya yang selama ini berlaku termasuk perkara mutasyabihat. ${ }^{51}$ Lajnah Bahtsul Nahdatul Ulama juga telah mengeluarkan fatwa tentang bunga uang ini. Menurut Lajnah, hukum bank dan hukum bunganya sama seperti hukum gadai. Terdapat tiga pendapat ulama

${ }^{48}$ Wahbah al-Zuhaily, Fiqih..., h. 325

49 Malik ibn Anas ibn Malik ibn 'Amir al-Ashbahi al-Madani, al-Muwatha', ( Abu Dhabi, Muassasah Zaid ibn Sulthan, 2003(, cet. 1, juz 4, h. 918

${ }^{50}$ Nasrun Haroen, Fiqih...,h. 269

${ }^{51}$ Sohari Sahrani, Fikih..., h. 60 
sehubungan dengan masalah ini; pertama haram, sebab termasuk utang yang dipungut oleh rente. Kedua halal, sebab tidak ada syarat pada waktu akad, sedangkan adat yang berlaku tidak dapat begitu saja dijadikan syarat. Dan yang ketiga syubhat, sebab ahli hukum berselisih pendapat tentangnya. Meskipun ada perbedaaan pandangan, Lajnah memutuskan bahwa pilihan yang lebih berhati-hati ialah pendapat yang pertama, yakni menyebut bunga bank adalah haram. ${ }^{52}$

Komisi Fatwa Majelis Ulama Indonesia juga telah mengeluarkan keputusan mengenai status hukum bunga (interest/fa'idah), di mana dalam fatwanya mereka mendefinisikan bunga sebagai suatu tambahan yang dikenakan dalam transaksi pinjaman uang (al-qardh) yang diperhitungkan dari pokok pinjaman tanpa mempertimbangkan pemanfaatan/hasil pokok tersebut, berdasarkan tempo waktu, diperhitungkan secara pasti di muka berdasarkan persentase. Dan yang dimaksud dengan riba oleh mereka adalah tambahan (ziyadah) tanpa imbalan yang terjadi karena penagguhan dalam pembayaran yang diperjanjikan sebelumnya, dan inilah yang disebut riba nasi'ah.

Setelah mereka menjelaskan apa yang dimaksud dengan bunga (fa'idah/interest) dan apa yang dimaksud dengan riba', mereka mengatakan bahwa praktek pembungaan uang saat ini telah memenuhi kriteria riba yang terjadi pada jaman Rasulullah SAW, yaitu riba nasi'ah. Dengan demikian, praktek pembungaan uang saat sekarang ini termasuk salah satu bentuk riba, dan riba haram hukumnya. Jadi, haram juga hukumnya menggunakan sistem pembungaan uang tersebut, baik itu dilakukan oleh Bank, Asuransi, Pasar Modal, Pegadaian, Koperasi, Dan Lembaga Keuangan lainnya maupun dilakukan oleh individu.

Selanjutnya Majelis Ulama Indonesia juga menetapkan bagaimana hukum bermu'amalah dengan menggunakan lembaga keuangan konvensional. Dan dalam hal ini Majelis Ulama Indonesia membaginya dalam dua kategori. Pertama, bagi wilayah yang sudah ada kantor/ jaringan lembaga keuangan syari'ah dan mudah dijangkau, tidak dibolehkan melakukan transaksi yang didasarkan kepada perhitungan bunga. Dan yang kedua, bagi wilayah yang belum ada kantor/ jaringan lembaga keuangan syari'ah, diperbolehkan melakukan kegiatan transaksi dengan lembaga keuangan konvensional berdasarkan prinsip dharurat/hajat. ${ }^{53}$

Jadi, dari fatwa tersebut jelas bahwa MUI mengatakan secara tegas bahwa praktek pembungaan yang terjadi sekarang ini sama dengan praktek riba pada zaman jahiliyah, maka dari itu bunga juga haram hukumnya, dan umat muslim tidak boleh bertransaksi dengan lembaga keuangan konvenional yang menggunakan sistem bunga, selama di wilayah tempat tinggalnya sudah ada lembaga keuangan syari'ah. Dan jika belum ada baru diperbolehkan karena kebutuhan.

\section{PEMAHAMAN PEDAGANG}

\section{TERHADAP FATWA DAN FAKTOR-}

FAKTOR PEDAGANG TIDAK

\section{MENGIKUTI FATWA MUI TENTANG KEHARAMAN INTEREST}

Pasar Aur Kuning dibangun pada tahun 1981. Letak Pasar Aur Kuning sangat strategis yaitu terletak di pusat Kota Bukittinggi dan juga didukung oleh sarana transportasi yang sangat mudah dicapai, yaitu dengan adanya terminal antar kota dan antar provinsi, sehingga hal itu sangat menguntungkan bagi pedagang, dan juga konsumen. Soal kualitas barang yang dijual di sana tidak kalah bersaing, bahkan menarik wisatawan dari negara tetangga untuk berbelanja ke Pasar Aur Kuning seperti, Malaysia, Singapura, dan Brunei. Rata-rata 
pengunjung pasar Aur Kuning perhari adalah kurang lebih 5.000 orang pengunjung, sedangkan hari libur, atau hari-hari besar sekitar 9.000 pengunjung kurang lebih. Dan dari data yang penulis dapat dari Dinas Pengelola Pasar Aur Kuning Bukittinggi luasnya adalah 2,3 hektar, yang di dalamnya terdapat toko sebanyak kurang lebih 1497 petak toko, ${ }^{54}$ tetapi dalam penelitian ini penulis hanya mengambil sampel dari beberapa blok pasar saja, yaitu blok A, blok B, bawah kantor, tahap 1, tahap 2, pasar konveksi, dan tokotoko yang berada di tepi jalan belakang Pasar Aur Kuning dengan jumlah responden 30 orang.

Untuk mengetahui bagaimana pemahaman para responden tentang fatwa, penulis memulai pertanyaan dengan bagaimana pengetahuan responden terhadap fatwa, dan hasil yang didapat adalah bahwa responden yang sangat tahu tentang fatwa itu berjumlah 2 orang dari 30 orang responden atau sebanyak $6,67 \%$ responden, artinya sangat sedikit responden yang mengatakan bahwa mereka sangat tahu apa yang dikatakan itu fatwa yaitu sebanyak 6,67\%. Hal ini menunjukkan bahwa sangat sedikit responden yang sangat paham apa itu yang dikatakan fatwa, siapa yang mengeluarkan fatwa tersebut, bagaimana kriteria seorang mufti, dan bagaimana hukum mengikuti fatwa tersebut. Kemudian, responden yang tahu tentang fatwa ini juga sedikit yaitu berjumlah 10 orang dari 30 orang responden atau sebanyak 33,33\% responden. Artinya 33,33\% responden ini tahu apa itu fatwa tapi hanya tahu sebatas defenisi saja, dan tidak tahu secara mendalam.

Selanjutnya, juga hanya sedikit responden yang hanya tahu sedikit tentang fatwa yaitu sebanyak $23,33 \%$ responden, artinya responden ini hanya pernah mendengar kata-kata fatwa, tetapi mereka tidak tahu apa itu yang dikatakan fatwa. Dan yang terakhir,

${ }^{54}$ Arsip, Daftar Toko Pasar Simpang Aur Kuning, Dinas Pengelolaan Koperasi, UKM, dan Perdagangan Kota Bukittinggi responden yang benar-benar tidak tau apa itu fatwa berjumlah 11 orang dari 30 orang responden, atau sebanyak 36,66\% responden. Artinya responden ini tidak tahu apa yang dimaksud dengan fatwa dan juga tidak mengenal kata fatwa itu sendiri. Jadi, cukup banyak responden yang hanya pernah mendengar kata-kata fatwa, tetapi mereka tidak tau apa maksud dari fatwa itu, tidak tau siapa yang mengeluarkan fatwa dan juga tidak tahu bagaimana hukum mengikuti fatwa tersebut. Kesimpulan ini juga dikuatkan dengan hasil observasi penulis ketika menyebarkan angket penelitian penulis, banyak responden yang bertanya ke penulis tentang perngetian fatwa tersebut.

Setelah mengetahui pengetahuan responden tentang fatwa, penulis menanyakan bagaimana pendapat responden tentang hukum mengikuti sebuah fatwa.Responden yang mengatakan mengikuti fatwa itu wajib berjumlah 8 orang dari 29 orang responden atau sebanyak $27,59 \%$ responden. Kemudian, responden yang mengatakan mengikuti fatwa itu hukumnya sunah berjumlah 6 orang dari 29 orang responden, atau sebanyak 20,69\% responden. Kemudian, responden yang berpendapat bahwa hukum mengikuti fatwa itu boleh berjumlah 15 orang dari 29 orang responden, atau sebanyak $51,72 \%$ responden. Dan tidak ada responden yang mengatakan bahwa mengikuti fatwa itu hukumnya haram. Hasil ini menunjukkan bahwa, cukup banyak responden yang mengatakan bahwa mengikuti fatwa itu hukumnya boleh diikuti dan boleh tidak, yaitu sebanyak 51,72\%.

Selanjutnya, penulis bertanya mengenai pengetahuan responden tentang fatwa MUI tentang keharaman interest. Responden yang mengatakan bahwa mereka sering kali mendengar fatwa MUI tentang haramnya bunga bank berjumlah 6 orang dari 30 orang responden, atau sebanyak 20,00\% responden. kemudian, responden yang mengatakan bahwa mereka pernah mendengar fatwa MUI tersebut berjumlah 20 orang dari 30 orang responden, 
atau sebanyak $66,67 \%$ responden. Selanjutnya responden yang mengatakan bahwa mereka tidak pernah mendengar fatwa MUI tersebut berjumlah 4 orang dari 30 orang responden, atau sebanyak 13,33\% responden. Dari hasil ini dapat ditarik kesimpulan bahwa, sangat banyak responden yang sudah mendengar fatwa MUI tentang bunga bank ini, yaitu sebanyak 86,67\% responden . Dan sangat sedikit responden yang mengatakan belum pernah mendengar tentang fatwa tersebut yaitu hanya $13,33 \%$ responden saja. Hal ini berarti bahwa fatwa tentang keharaman interest ini merupakan salah satu dari fatwa yang sangat populer dikalangan masyarakat. Karena fatwa ini dikeluarkan oleh MUI pusat, bukan hanya fatwa MUI daerah tertentu saja. Dan sikap responden terhadap fatwa MUI tersebut, bermacam-macam, responden yang mengatakan bahwa mereka sangat setuju dengan fatwa MUI yang mengatakan bahwa bunga bank itu sama dengan riba' berjumlah 15 orang dari 30 orang responden, atau sebanyak 50,00\% responden. Responden yang mengatakan bahwa mereka setuju dengan fatwa MUI tersebut berjumlah 11 orang dari 30 orang responden, atau sebanyak 36,66\% responden. Dan terakhir, responden yang mengatakan bahwa mereka tidak setuju dengan fatwa MUI tersebut berjumlah 4 orang dari 30 orang responden, atau sebanyak 13,33\% responden.

Dari hasil ini penulis menyimpulkan bahwa sangat banyak responden setuju dengan isi fatwa MUI tersebut, hanya 13,33\% responden saja yang mengatakan bahwa mereka tidak setuju dengan isi fatwa MUI itu. Kemudian, penulis juga ingin tahu bagaimana responden menanggapi isi kedua dari fatwa tersebut, akan dibahas lebih lanjut pada tabel 4.17 .

Terhadap isi fatwa yang kedua yaitu MUI mengatakan jikalau ada lembaga keuangan syari'ah di sebuah tempat maka tidak boleh bertransaksi dengan menggunakan bank konvensional. Ada responden yang mengatakan sangat setuju dengan isi fatwa MUI yang kedua itu berjumlah 5 orang responden dari 28 orang reponden, atau sebanyak $17,86 \%$ responden. Kemudian, responden yang mengatakan bahwa mereka setuju dengan isi fatwa tersebut berjumlah 18 orang dari 28 orang responden, atau sebanyak $64,28 \%$, dan responden yang mengatakan bahwa mereka tidak setuju dengan isi fatwa tersebut berjumlah 5 orang dari 28 orang responden, atau sebanyak 17,86\% responden. Dapat disimpulkan bahwa sangat banyak responden itu setuju dengan fatwa yang dikeluarkan oleh Majelis Ulama Indonesia. Dan dari hasil ini juga dapat penulis menyimpulkan bahwa, walaupun para pedagang tersebut menganggap hukum mengikuti fatwa boleh, mereka setuju dengan isi fatwa MUI tentang keharaman interest yang mengatakan bahwa bunga bank itu sama dengan riba', dan hukumnya haram, dan juga mereka setuju jikalau di sebuah tempat ada lembaga keuangan syari'ah tidak boleh bertransaksi dengan menggunakan lembaga keuangan konvensional.

Dan untuk mengetahui apa faktor penyebab responden tidak mengikuti fatwa tersebut dapat dilihat dari beberapa hasil penelitian ini. Pertama, yaitu jawaban responden tentangbagaimana mereka hukum mengikuti fatwa, dan didapatkan hasil, responden yang mengatakan mengikuti fatwa itu wajib berjumlah 8 orang dari 29 orang responden atau sebanyak $27,59 \%$ responden, responden yang mengatakan mengikuti fatwa itu hukumnya sunah berjumlah 6 orang dari 29 orang responden, atau sebanyak 20,69\% responden, responden yang berpendapat bahwa hukum mengikuti fatwa itu boleh berjumlah 15 orang dari 29 orang responden, atau sebanyak $51,72 \%$ responden. Dan tidak ada responden yang mengatakan bahwa mengikuti fatwa itu hukumnya haram. Hasil ini menunjukkan bahwa, cukup banyak responden yang mengatakan bahwa mengikuti fatwa itu hukumnya boleh diikuti dan boleh tidak, yaitu 
sebanyak 51,72\%. Hasil ini menunjukkan, sangat banyak responden juga mengatakan bahwa hukum mengikuti pendapat ulama itu tergantung pada persoalannya, artinya boleh diikuti, dan boleh tidak diikuti.

Kedua, jawaban responden dari pertanyaan bagaimana sikap mereka jika dikasih bunga bank, dan didapatkan hasil, responden yang tidak mau menerima bunga bank berjumlah 12 orang dari 30 orang responden, atau sebanyak $40,00 \%$ responden, artinya $40,00 \%$ responden ini menganggap bunga merupakan sesuatu yang tidak boleh diterima, lalu mereka menolak untuk mengambilnya. Responden yang mengatakan bahwa bunga bank itu boleh diterima jikalau sedikit berjumlah 11 orang dari 30 orang responden, atau sebanyak 36,66\% responden, artinnya responden ini menganggap bolehboleh saja menerima bunga itu jikalau jumlahnya sedikit tetapi baru tidak boleh diterima jikalau jumlahnya banyak. Responden yang mengatakan bahwa bunga bank itu boleh diterima sedikit atau banyak berjumlah 6 orang dari 30 orang responden, atau sebanyak $20,00 \%$ responden, artinya responden ini menganggap bahwa bunga bank itu boleh saja diterima, baik itu sedikit maupun banyak. Dan ada 1 responden dari 30 orang responden atau sebanyak 3,33\% responden yang mengisi sendiri pilihannya dengan mengatakan terima saja, artinya responden ini juga menganggap bunga bank itu boleh saja di terima. Jadi, ada cukup banyak responden yang mengatakan tidak boleh mengambil bunga bank tersebut, yaitu sebanyak 40,00\% responden, dan banyak responden yang menganggap bahwa bunga bank itu boleh diterima yaitu sebanyak $60.00 \%$.

Ketiga, jawaban responden dari pertanyaan mana yang akan mereka pilih, bertransaksi dengan menggunakan bank konvensional atau bank syari'ah. Responden yang memilih bertransaksi dengan menggunakan bank konvensional ketimbang bank syari’ah dengan alasan bank konvensional lebih baik dan nyaman berjumlah 2 orang dari 30 orang responden, atau sebanyak 6,67\% responden. Responden yang memilih bank syari'ah dibanding bank konvensional karena bank syari'ah lebih baik dan nyaman sebanyak 15 orang dari 30 orang responden, atau sebanyak 50,00\% responden. Responden yang lebih memilih bertransaksi dengan menggunakan bank konvensional dibanding bank syari'ah dengan alasan bank konvensional ada bunganya berjumlah 7 orang dari 30 orang responden, atau sebanyak 23,33\% responden. Dan terakhir responden yang lebih memilih bertransaksi dengan menggunakan bank syari'ah dibanding bank konvensional karena bank syari'ah itu tidak ada bunganya berjumlah 6 orang dari 30 orang responden, atau sebanyak 20,00\% responden. Dari tabel ini penulis menyimpulkan bahwa banyak responden yang lebih memilih bank syari'ah ketimbang bank konvensional yaitu sebanyak 21 orang responden atau 70,00\%. Dan hanya sedikit responden yang mengatakan bahwa mereka lebih memilih menggunakan bank konvensional yaitu $30.00 \%$ responden saja.

Kemudian, sembari penulis menyebarkan angket ini ada beberapa responden yang mengatakan bahwa kalau bisa memilih mereka lebih memilih menggunakan bank syari'ah ketimbang bank konvensional, tetapi walaupun bank syari'ah sudah ada di Pasar Aur Kuning, ketika mereka membeli barang di Pasar Tanah Abang Jakarta, bank syari'ah itu letaknya jauh dari pasar dan menyulitkan mereka untuk bertransaksi. Ada juga responden yang mengatakan bahwa susah menggunakan transaksi kartu debit dengan menggunakan bank syari'ah. Lalu penulis menyimpulkan bahwa salah satu faktor lagi yang menyebabkan Pedagang Pasar Aur Kuning itu tidak mengikuti fatwa MUI tentang haramnya interest karena fasilitas bank syari'ah belum selengkap fasilitas bank konvensional.Dan ada juga responden yang menganggap bahwa bertransaksi dengan menggunakan bank konvensional itu sama saja 
dengan bertransaksi dengan menggunakan bank syari'ah, karena mereka menganggap bahwa sistem bunga yang diterapkan oleh bank konvensional itu sama dengan konsep bagi hasil yang diterapkan bank syari'ah, kemudian mereka juga menganggap uang yang ada di bank konvensional, dan uang yang ada di bank syari'ah itu sama-sama bermuara pada Bank Indonesia sebagai bank sentral, dan Bank Indonesia tidak memakai sistem syari'ah.

\section{KESIMPULAN}

Pemahaman pedagang tentang fatwa yaitu kebanyakan pedagang hanya pernah mendengar kata fatwa, tetapi tidak tau apa yang dimaksud dengan fatwa tersebut, pedagang tidak tau bahwa seorang mufti yang mengeluarkan fatwa itu harus memenuhi beberapa persyaratan terlebih dahulu, pedagang memahami fatwa sebagai suatu yang boleh diikuti dan boleh tidak diikuti, mereka setuju dengan isi fatwa MUI tentang keharaman interest, walaupun mereka beranggapan bahwa fatwa itu tidak wajib diikuti.

Dan yang menjadi faktor pedagang Pasar Aur Kuning tidak mengikuti fatwa MUI tentang keharaman interest adalah pertama, karena kebanyakan dari mereka tidak terlalu paham masalah-masalah keagamaan seperti isi dari fatwa, kedua, mereka menganggap bahwa pendapat ulama itu diikuti tergantung persoalan yang dibicarakan, jadi menurut penulis fatwa ini menjadi salah satu fatwa yang tidak diikuti oleh pedagang tersebut, dan memang fatwa tidak memiliki kekuatan hukum yang mengikat, jadi fatwa boleh diikuti dan juga boleh tidak diikuti termasuk fatwa MUI tentang keharaman interest ini, ketiga,fasilitas bank syari'ah tidak selengkap fasilitas bank konvensional, hal ini membuat para pedagang masih menggunakan bank kovensional, jikalau mereka benar-benar meninggalkan bank konvensional, mereka akan kesulitan dalam bertransaksi dalam membeli barang atau menjual barang dagangan mereka.Keempat, karena masih banyak pedagang menganggap bahwa bunga bank itu boleh saja diterima, bagi mereka sistem bunga bank yang digunakan oleh bank konvensional itu, sama saja dengan konsep bagi hasil yang diterapkan oleh bank syari'ah. 


\section{DAFTAR KEPUSTAKAAN}

Abbas, Anwar, dkk, Pedoman Penyelenggaraan Organisasi Majelis Ulama Indonesia. Jakarta: MajelisUlama Indonesia, 2010

Ali, Zainuddin, Hukum Perbankan Syari'ah. Jakarta: Sinar Grafika, 2010

Amin, Ma'ruf, M. Ichwan Sam, dkk, Himpunan Fatwa Majelis Ulama Indonesia Sejak. 1975. Jakarta: Erlangga, 2011

Antonio, Muhammad Syafi'i, Bank Syari'ah dari Teori ke Praktik. Jakarta: Gema Insani, 2013

Anwar, Desi, Kamus Lengkap Satu Milliard. Surabaya: Amelia, 2003

Arsip, Daftar Toko Pasar Simpang Aur Kuning. Bukittinggi: Dinas Pengelolaan Koperasi, UKM, dan Perdagangan Kota Bukittinggi

Asyqar, Muhammad Sulaimân Abdullah al-, al-Futyâ wa Manâhij al-iftâ'Babtsu Ushûliy. Cet. 1. Kuweit: Maktabah al-Manâr al-Islâmiyah, 1976

Bukhârî, Muhammad ibn Ismâ'îl Abû 'Abdillah al-, al-Jâmi' al-Musnad al-Shahîh al-Mukhtashar min Umûr Rasûlillah SAW wa Sunanub wa Ayyâmub. Cet. 1, juz, 1, 3, 5. Damaskus: Dâr Thûq alNajâh, 1422 H

Busyro, Fatwa Responsif. Bukittinggi: STAIN Bukittinggi, 2013

Darmawi Herman, Pasar Finansial dan Lembaga-Lembaga Finansial. Jakarta: Bumi Aksara, 2006

Djalil, Basiq, Peradilan Islam. Jakarta: Bumi Aksara, 2012

Haroen, Nasrun, Fiqh Muamalah. Jakarta: Gaya Media Pratama, 2000

https://almanaar.wordpress.com/2008/04/16/ fatwa-mui-tentang-bunga-bank/ pada tanggal 15 April 2017

Isfahâni, al-Râghib al-, Mu'jam Mufradât al-Alfẫ̧̧ al-Qur ân. Beirut: Dâr al-Fikr, [tth]

Iska, Syukri, Sistem Perbankan Syariah di Indonesia dalam Perspektif Fiqib Ekonomi, Yogyakarta: Fajar Media Press, 2012

Kasmir, Dasar-dasar Perbankan. Jakarta: Raja Grafindo Persada, 2002

Khallaf, Abdul Wahab, Ilmu Ushul Figh. Semarang: Dina Utama, 1994

Khosyi'ah, Siah, Fiqh Muamalah Perbadingan. Bandung: Pustaka Setia, 2014

Madani, Malik ibn Anas ibn Malik ibn 'Amir al-Ashbahi al-, al-Muwatha'. Cet. 1, juz 4. Abu Dhabi, Muassasah Zaid ibn Sulthan, 2003

Mâjah, Abû Abdillâh Muhammad ibn Yazîd al-Quzwainîy Ibn, Sunan Ibn Mâjah. Juz 2. Dâr alIhyâ' al-Kutub al-'Arabiyah, [tth]

Manzhûr, Muhammad ibn Mukarram ibn 'Ali Jamal al-Din ibn, Lisan al-'Arab. Cet. Ke-3. Jilid 5. Beirut: Dar Shadir, 1414 H

Munawwir, Achmad Warson dan Muhammad Fairuz, Al-Munawwir Kamus Indonesia -Arab. Surabaya: Pustaka Progresif, 2007 
Naisabûrî, Muslim ibn al-Hajjâj Abû al-Hasan al-Qusyairi al-, Musnad al-Ṣabîh al-Muktașar bi Naql al-adl Ilâ Rasûlillâh $S A W$. Juz 3. Beirut: Dâr Ihyâ’ al-Turâs al-'Arabi, [tth]

Perwataatmadja, Karnaen A. dan Hendri Tanjung, Bank Syariah. Jakarta: Celestical Publishing, 2011

Qarâdhâwi, Yûsuf al-, al-Fatwâ Bain al-Indhibâth wa al-Tasayyub. Cet. 1. Kairo: Dâr al-Shahwah li alNasyar wa al-Tawzî̀, 1988

Qarâdhâwi, Yûsuf al-, Bunga Bank Haram. Jakarta: Akbar, 2003

Qarâdhâwi, Yûsuf al-, Fatwa antara Ketelitian dan Kecerobohan. Jakarta: Gema Insani, 1997

Qâsimîy, Muhammad Jamâl al-Dîn al-, al-Fatwâ fí al-Islâm. Cet. 1. Beirut: Dâr al-Kutub al-'Ilmiyah, 1986

Rahman, Asymuni A., dkk, Ushul Fiqh Qaidab-Qaidah Istinbath dan Ijtihad. Jakarta: Departemen Agama, 1986

Sabiq, Sayyid, Fikih Sunnah 5. Jakarta: Cakrawala Publishing, 2012

Sudirman, I Wayan, Manajemen Perbankan. Jakarta: Kencana Prenada, 2013

Wirdyaningsih, Bank dan Asuransi Islam di Indonesia. Jakarta: Kencana Prenada Media, 2005

Zuhaily, Wahbah al-, Fiqib Islam wa Adillatubu (terjemahan). Jakarta: Gema Insani, 2011 